\title{
KETIDAKSTABILAN BESARAN STOK IKAN DARI MODEL PRODUKSI SURPLUS
}

\author{
Suherman Banon Atmaja \\ Peneliti pada Balai Riset Perikanan Laut, Muara Baru-Jakarta \\ Komplek Pelabuhan Perikanan Samudera Jl. Muara Baru Ujung-Jakarta 14440, E-mail: kanlutmb@indosat.nei.id
}

\begin{abstract}
ABSTRAK
Selama ini, kerangka pengelolaan sumber daya ikan berdasarkan pada titik acuan nilai potensi dan kriteria maksimum (maximum sustainable yield), mengabaikan laju pertumbuhan stok ikan dan tanpa memperhatikan dinamika perikanan yang terjadi. Dari kombinasi data yang tersedia diperoleh hasil besaran nilai stok ikan yang bersifat dinamis, akibat perubahan yang terjadi pada parameter-parameter model produksi surplus. Tingkat maximum sustainable yield menunjukkan $\mathrm{C}_{\mathrm{MSY}}$ dari metode Gompertz lebih tinggi dibandingkan dengan metode logistik, sebaliknya tingkat $\mathrm{E}_{\mathrm{MSY}}$ lebih rendah dibandingkan dengan metode logistik. Konsekuensi perbedaan tersebut menghasilkan tingkat $\mathrm{B}_{\mathrm{MSY}}$ dan tercapai puncak titik jenuh dari perikanan pukat cincin berbeda, untuk metode Gompertz (37\% dari biomassa awal) terjadi pada kurun waktu tahun 1978 sampai dengan 1981, sedangkan untuk metode logistik (50\% dari biomassa awal) terjadi pada kurun waktu tahun 1990 sampai dengan 1992. Kondisi trend biomassa menunjukkan penurunan biomassa berkisar 92 sampai dengan 96,5\% dari biomassa awal untuk metode Gompertz, sedangkan untuk metode logistik berkisar 70 sampai dengan $93 \%$. Tampak perkembangan perikanan pukat cincin catch effort mengikuti fungsi pertumbuhan logistik daripada fungsi pertumbuhan Gompertz. Bagaimanapun, penyusutan stok ikan pelagis didukung oleh trend hasil tangkapan yang menurun, sedangkan hari operasi cenderung meningkat.
\end{abstract}

\section{KATA KUNCI: ketidakstabilan, stok ikan, produksi surplus}

\section{ABSTRACT: Unstablility of size of fish stock analized using surplus production model. By: Suherman Banon Atmaja}

During the time, framework of fisheries resources management was based on reference point of potency value and criteria (maximum sustainable yield), while net growth of fish stock and fisheries dynamics have been ignored. From data combination available obtaining result of size of fish stocks was dynamic due to change of parameters of surplus production. The Level maximum sustainable yield showes that $C_{M S Y}$ method of Gompertz was higher than logistics method, on the contrary $E_{M S Y}$ compared to lower than logistics method. Consequently, these results were obtained the level of $B_{M S Y}$ (biomass at level maximum sustainable yield) and the peaks of exploitation from purse seine fishery were also diffrent, for Gompertz method revealed that the level of $B_{M S Y}$ (37\% from initially biomass) occurred in the period of 1978 to 1981, while logistics method (50\% from initially biomass) occurred in the period of 1990 to 1992. Trend biomass in state of decline reached 92 to 96,5\% from intially biomass for Gompertz method, while for the method of logistics reached 70 to $93 \%$ from intially biomass. Seems that the development of purse seine fisheries (catch effort) followed function growth logistics rather than the function growth Gompertz. However, the decrease of fish stock pelagic supported by the catch of pelagic fish showed a declining trend, while fishing days have tend to increase.

\section{KEYWORDS: $\quad$ unstablility, fish stock, surplus production}

\section{PENDAHULUAN}

Ketidakpastian dalam ketersediaan informasi untuk mengelola stok ikan yang dieksploitasi telah dikenal luas akhir-akhir ini. Kurang cukup data dan tidak terdeteksi lebih tangkap (overfishing) adalah faktor terjadi unsustainability dan overexploitation. Dalam kajian stok ikan akan menghadapi besaran nilai stok ikan yang bersifat dinamis dan ketidakpastian populasi yang benar, maka hasil dan kesimpulan yang diperoleh dari beberapa peneliti akan berbeda-beda. Berbagai penelitian menunjukkan bahwa stok ikan adalah kuantitas yang berubah, secara umum terjadi penyusutan stok ikan ditimbulkan oleh 2 penyebab utama, yaitu akibat kegiatan manusia (anthrophogenic causes) dan akibat alam (natural causes). Kegiatan manusia yang menyebabkan terjadi penyusutan stok ikan antara lain 1) penangkapan ikan dengan menggunakan alat dan metode yang merusak; dan 2) penangkapan yang berlebih dan tidak seimbang tingkat pemanfaatan dengan kelestarian. Sedangkan akibat alam antara lain pemanasan global (global warming), fenomena alam lain seperti El-Nino, La-Nina, dan lainlain. Charles (2001) mengatakan bahwa 2 sumber ketidakpastian dalam sistem perikanan, yaitu alam (besaran stok dan struktur umur, kematian alami, migrasi, dan parameter stock recruitmen, interaksi dari multi spesies, dan interaksi lingkungan dengan ikan), 
kegiatan manusia (perubahan teknologi, harga ikan dan struktur pasar, biaya operasional dan oportunitas, dan persepsi status stok). Caddy \& Mcgarney (1996) telah menyimpulkan bahwa komponen ketidakpastian dialamatkan kepada tingkat kepercayaan struktur model dan pendugaan parameter (biomassa atau kelimpahan populasi, kematian alami dan penangkapan, dan kemampuan tangkap). Walters (1984) diacu dalam Badrudin \& Blaber (2003) mengatakan bahwa manajemen perikanan dihadapkan kepada 3 jenis ketidakpastian, yaitu variasi alam lingkungan yang tidak dapat diramalkan dengan hasil yang memuaskan, kesalahan dalam pendugaan parameter model produksi, dan ada perubahan yang terus berlangsung dari parameter-parameter tersebut. Hilborn \& Peterman (1996) diacu dalam Seijo et al. (1998) mengidentifikasi 7 sumber ketidakpastian dalam pendugaan stok perikanan, yaitu pendugaan kelimpahan stok, struktur model matematik pada perikanan, kapan pendugaan parameter model, kondisi lingkungan masa depan, respon pengguna terhadap regulasi, sasaran pengelolaan masa depan dan kondisi ekonomi, politik dan sosial. Freon (1986) mengatakan aplikasi model produksi surplus tidak cocok untuk stok ikan tertentu, karena variasi upaya penangkapan hanya menerangkan sebagian kecil dari variabilitas total dari hasil tangkapan tahunan. Kerapkali varibilitas sisa berasal dari pengaruh klimat yang mengganggu kelimpahan stok dan koefisien kemampuan tangkap. Marr (1981) mengatakan bahwa perikanan tropis sebagaimana telah diketahui, sebagai usaha perikanan yang multi species. Sedangkan teori dinamika populasi ikan merupakan alat pengelolaan utama yang dikembangkan dari usaha perikanan 1 jenis ikan di daerah beriklim sedang, tidak dapat diterapkan dengan sempurna pada perikanan tropis multi species.

Model regresi produksi surplus yang dikembangkan oleh Walters \& Hilborn (1976) dalam Hilborn \& Walters (1992); Schnute (1977) dalam Hilborn \& Walters (1992) adalah tipe ke-3 setelah Schaefer (1954); Pella \& Tomlinson (1969) dalam Hilborn \& Walters (1992); Fox (1975) dalam Hilborn \& Walters (1992), di mana model Walters \& Hilborn menggunakan versi discrete, sedangkan Schnute melalui prosedur integrasi. Pendugaan parameter produksi surplus dari fungsi Gompertz oleh Clarke et al. (1992) adalah versi ke-2 setelah Fox (1975). Model ini dapat memberi suatu uraian yang bermanfaat tentang suatu perikanan dan aplikasi memberi gambaran keseimbangan bagi spesies berumur pendek sebagaimana ikan pelagis kecil.

Pada model Walters \& Hilborn dan Schnute dapat memperlihatkan chaotic behavior untuk nilai $r$ (laju pertumbuhan intrinsik) yang tinggi, sedangkan pada nilai $r$ dan $\mathrm{q}^{\star} \mathrm{E}$ rendah, model ini tidak jauh berbeda dengan
Schaefer model (Fauzi, 1999). Penggunaan tingkat upaya penangkapan sama $\left(E_{t}\right)$ untuk masing-masing spesies akan memperoleh ketidaksesuaian yang mencolok antara kurva pertumbuhan bersih stok setiap spesies dengan kecepatan perkembangan produksi. Aplikasi model produksi surplus berdasarkan pada spesies dapat menyebabkan hasil yang tidak menentu, sering ditemukan dalam other mixed species perikanan tropis (Pauly, 1979 diacu dalam Hilborn \& Waters, 1992).

Tujuan tulisan ini mencoba menganalisis kembali berbagai kemungkinan dari kombinasi data yang tersedia, untuk memperlihatkan dalam pendugaan stok ikan dengan menggunakan model produksi surplus akan diperoleh ketidakstabilan tingkat (maximum sustainable yield) akibat perubahan dari parameter-parameter yang dihasilkan. Pendekatan dinamika biomassa dan mortalitas penangkapan maksimum $\left(F_{M S Y}\right)$ untuk mengambarkan kondisi sumber daya ikan pelagis kecil di Laut Jawa.

\section{BAHAN DAN METODE}

Ikan-ikan pelagis kecil di Laut Jawa ditangkap dengan menggunakan berbagai jenis alat tangkap baik di perairan pantai maupun di perairan lepas pantai, di mana sebagian besar produksi berasal dari armada pukat cincin. Lima spesies utama hasil tangkapan kapal pukat cincin, yaitu ikan layang (Decapterus russelli dan Decapterus macrosoma), bentong (Selar crumenophthalmus), banyar (Rastrelliger kanagurta), dan siro (Amblygaster sirm). Kelima spesies tersebut memberi kontribusi lebih dari $90 \%$, kecuali di wilayah penangkapan utara Jawa Tengah sampai dengan Kepulauan Karimunjawa kurang dari 70 \% (Atmaja \& Sadhotomo, 2000).

Data hasil tangkapan dan upaya penangkapan perikanan pukat cincin komersial dikumpulkan di pangkalan Pekalongan dan Juana selama periode tahun 1976 sampai dengan 2004. Data produksi pukat cincin di ke-2 tempat tersebut mewakili sekitar $30 \%$ dari produksi 5 kategori komersial pelagis kecil di seluruh Laut Jawa dan $45 \%$ dari seluruh produksi perikanan pukat cincin di Laut Jawa dan sekitar. Rendah kontribusi produksi pukat cincin tersebut akibat trend yang berlawanan antara produksi pukat cincin dengan statistik perikanan Indonesia (Lampiran 1).

Untuk mengetahui perubahan stok ikan per waktu setelah dilakukan penangkapan dalam penelitian ini menggunakan 2 cara, yaitu model produksi surplus Schaefer dan prosedur (Clarke et al., 1992). Pada model Schaefer, laju pertumbuhan bersih stok ikan digambarkan sebagai fungsi logistik, sedangkan pada 
Clarke et al. (1992) laju pertumbuhan bersih stok ikan diasumsikan sebagai fungsi Gompertz.

Perubahan stok ikan per waktu akibat penangkapan adalah selisih antara laju pertumbuhan stok dikurangi dengan hasil tangkapan (C) secara matematik dapat ditulis, fungsi logistik:

$F(B)=\partial B / \partial t=r B_{t}\left(1-B_{t} / K\right)-C$

fungsi gompertz:

$F(B)=\partial B / \partial t=r B_{t} L n\left(K / B_{t}\right)-C$

Pendugaan parameter produksi surplus ( $r$, q, dan $\mathrm{K}$ ) secara terpisah menggunakan prosedur Walters \& Hilborn (1976) diacu dalam Hilborn \& Walters (1992) dan (Clark et al., 1992).

Pendekatan Walters \& Hilborn (1976) diacu dalam Hilborn \& Walters (1992) sebagai berikut:

$$
\left(U_{t+1} / U_{t}\right)-1=r-(r / q K) U_{t}-q E_{t} Y=\beta_{0}-\beta_{1} X_{1}-\beta_{2} X_{2} \ldots \ldots \ldots
$$

Pendekatan Clarke et al. (1992) sebagai berikut:

$$
\begin{aligned}
& \operatorname{Ln}\left(U_{t+1}\right)=2 r /(2+r) \operatorname{Ln}(q K)+(2-r) /(2+r) \ln \left(U_{t}\right)-q /(2+r)\left(E_{t}+E_{t+1}\right) \\
& \text { atau } \\
& Y=\beta_{0}+\beta_{1} X_{1}-\beta_{2} X_{2} \ldots \ldots \ldots \ldots \ldots \ldots \ldots \ldots \ldots \ldots \ldots \ldots \ldots \ldots \ldots \ldots \ldots \ldots \ldots \ldots \ldots \ldots \ldots \ldots \ldots
\end{aligned}
$$

Fungsi produksi $\left(\mathrm{C}=\mathrm{q}^{*} \mathrm{~B}^{\star} \mathrm{E}\right)$ diformulasikan untuk penggunaan model sustainable yield dalam jangka panjang dan biomassa (B) dalam persamaan tersebut adalah fungsi jangka panjang dari upaya penangkapan, di mana suatu kenaikan upaya penangkapan akan menyebabkan penurunan biomassa (Doll, 1988). Dalam notasi sederhana tersebut tidak diungkapkan asumsi sama dengan konsentasi ikan di daerah penangkapan.

Estimasi biomassa, pada kondisi pertumbuhan biomassa ikan sama dengan hasil tangkapan dari persamaan 1 diperoleh hubungan linier antara upaya penangkapan dengan biomassa, yakni:

$$
B=K-\left(K^{*} q / r\right)^{\star} E
$$

dan persamaan 2 diperoleh hubungan eksponensial, yakni:

$$
B=K^{\star} E X P\left(-q^{\star} E / r\right)
$$

di mana:

$$
\begin{aligned}
& \mathrm{C}=\text { hasil tangkapan } \\
& \mathrm{q}=\text { koefisien kemampuan tangkap }
\end{aligned}
$$

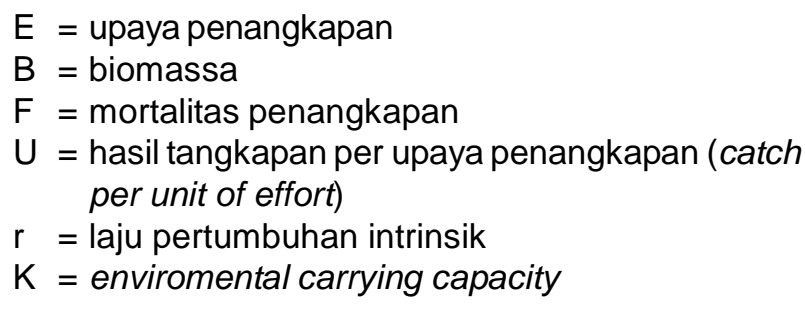

\section{HASIL DAN BAHASAN}

Hasil kajian stok ikan pelagis berdasarkan pada data hasil tangkapan dan upaya penangkapan runtun waktu tahun 1975 sampai dengan 1979 (sebelum pelarangan alat tangkap trawl, di mana sebagian besar kapal pukat cincin beroperasi di daerah penangkapan tradisional) diperoleh nilai potensi ikan pelagis 290.000 sampai dengan 391.000 ton per tahun (Bailey et al., 1987), angka potensi tersebut adalah kisaran nilai maximum sustainable yield yang dihitung dengan model Schaefer dan Gulland-Fox. Hasil perhitungan dengan model yang sama (dari sumber data hasil tangkapan dan upaya penangkapan runtun waktu tahun 1975 sampai dengan 1981. Produksi tertinggi terjadi pada tahun 1981, yaitu 227.700 ton) diperoleh kisaran nilai maximum sustainable yield 261.000 sampai dengan 312.000 ton (Dwipongggo, 1983). Kemudian hasil kajian stok tahun 2000, diperoleh nilai dugaan potensi pelagis di Laut Jawa dan Selat Sunda, yaitu 340.000 ton (Sumadiharga, 2000). Direktorat Jenderal Perikanan Tangkap (2004) mengatakan laju eksploitasi ikan pelagis kecil sekitar 1,5 (potensi $=340.000$ ton dan produksi $=507.530$ ton . Dari kajian tersebut tercermin bahwa stok ikan bersifat konstan dan tidak terlihat nyata kenaikan produksi ikan pelagis sebelum dan setelah pelarangan trawl dan dampak dinamika perikanan, yaitu perubahan yang terjadi pada perikanan pukat cincin baik kapasitas penangkapan (ukuran kapal dan termasuk kekuatan mesin), maupun ekspansi daerah penangkapan dan peningkatan efisiensi penangkapan melalui penggunaan cahaya (lampu sorot) sebagai alat bantu pengumpul ikan menggantikan peranan rumpon.

Berdasarkan pada data statistik perikanan Indonesia selama runtun waktu tahun 1976 sampai dengan 2003 mempelihatkan trend perkembangan produksi 5 kategori komersial (layang, selar, lemuru, tembang, dan kembung) naik 2 kali lipat dari periode sebelum pelarangan trawl, produksi perikanan pukat cincin di Laut Jawa dan sekitar naik 3 kali lipat, serta produksi perikanan pukat cincin di Pekalongan dan Juwana naik 4 kali lipat (Gambar 3). 


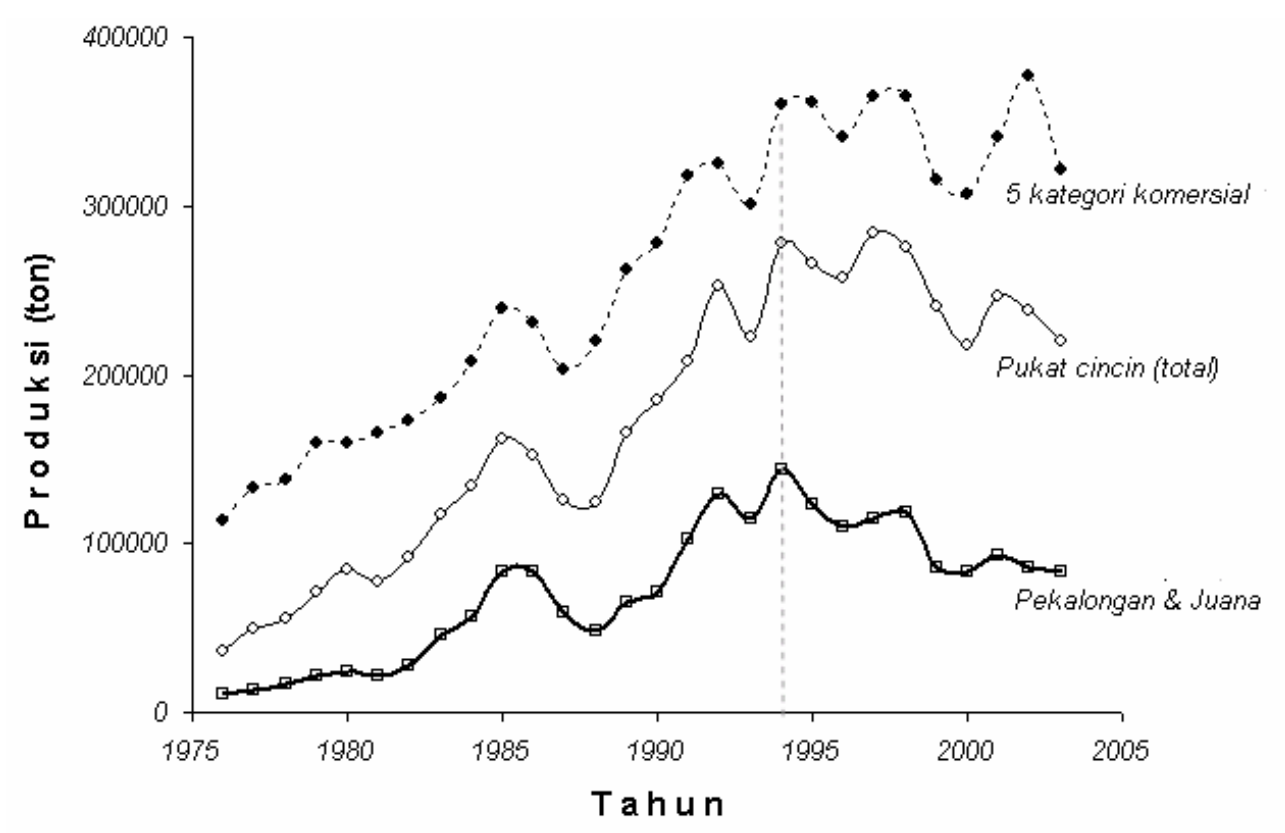

Gambar 1. Trend produksi 5 kategori komersial utama (layang, selar, lemuru, tembang, dan kembung), produksi perikanan pukat cincin di Laut Jawa dan sekitar, serta produksi perikanan pukat cincin di Pekalongan dan Juwana.

Figure 1. Trend production of five comercially category (scads, trevallies or yellow strip trevallies, spotted sardine, fringescale sardinella, and Indo-Pacific mackerels), production of purse siene in the Java Sea and adjacent waters, and production of purse siene in Pekalongan and Juwana landing site.

Pada Gambar 3 memperlihatkan pola fluktuasi produksi dari Pekalongan dan Juwana dan perikanan pukat cincin di seluruh Laut Jawa dan sekitar mempunyai kemiripan, tetapi jika diperhatikan fluktuasi produksi mempunyai kejadian puncak berbeda. Pada produksi yang berasal dari Pekalongan dan Juwana terjadi pada tahun 1994 dan telah mencapai kestabilan jangka panjang, sedangkan produksi perikanan pukat cincin di seluruh Laut Jawa dan sekitar telah mencapai kestabilan berlangsung pada tahun 1998, selanjutnya produksi menurun. Produksi dari 5 kategori komersial berlangsung pada tahun 1997 sampai dengan 1998, selanjutnya produksi menurun dan naik kembali pada tahun 2002 yang lebih besar dari puncak tahun sebelum. Hal ini, dapat diartikan bahwa produksi dari 5 kategori komersial belum mencapai stabilitas. Apabila catch per unit of effort kapal pukat cincin Pekalongan dan Juwana digunakan sebagai upaya penangkapan baku, maka akan diperoleh kenaikan upaya penangkapan yang tidak dibarengi dengan penurunan hasil tangkapan. Hal ini, tentu berlawanan dengan kenaikan upaya penangkapan perikanan pukat cincin dibarengi trend hasil tangkapan yang menurun.

\section{Laju Pertumbuhan Fungsi Logistik vs Gompertz}

Perubahan kelimpahan stok ikan dipengaruhi 3 parameter dari produksi surplus, yaitu pertumbuhan intrinsik ( $\mathrm{r}$ ), carring capacity $(\mathrm{K})$, koefisen kemampuan tangkap (q), ke-3 parameter ini sangat menentukan besaran stok ikan dan hasil tangkapan. Dari kombinasi data yang tersedia (Lampiran 1) diperoleh nilai laju pertumbuhan intrinsik ( $r$ ) dan kelimpahan stok ikan $(\mathrm{K})$ sangat bervariasi, di mana ke-2 parameters tersebut merupakan pasangan yang saling berkaitan. Kelimpahan stok ikan yang semakin besar akan diikuti dengan laju pertumbuhan intrinsik semakin kecil dan sebaliknya (Gambar 1 dan Lampiran 2). Besaran biomassa dan tingkat $\mathrm{C}_{\mathrm{MSY}}$ dari metode gompertz lebih tinggi dibandingkan dengan metode logistik, sebaliknya tingkat $E_{M S Y}$ memperlihatkan bahwa lebih rendah dari metode gompertz dibandingkan dengan metode logistik (Tabel 1 dan 2). Dengan demikian, ke-2 metode tersebut diperoleh tingkat maximum sustainable yield $\left(\mathrm{C}_{\mathrm{MSY}}\right.$ dan $\mathrm{E}_{\text {MSY }}$ ) yang tidak stabil. 

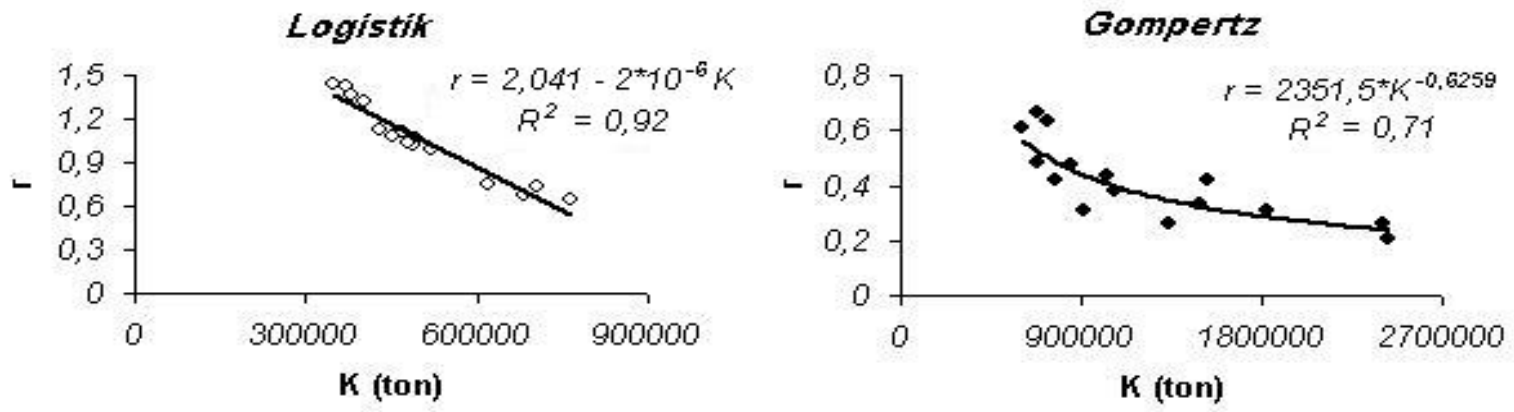

Gambar 2. Hubungan laju pertumbuhan intrinsik ( $r)$ dengan kelimpahan stok ikan $(K)$, logistik: $345.000<K<766000$ dan $0,65<r<1,44$; gompertz: $679.000<K<2430000$ dan $0,2<r$ 0,64.

Figure 2. Relationship between intrinsic of growth $(r)$ and stock fish abundance $(K)$, logistic: $345,000<K<766,000$ and $0.65<r<1.44$; gompertz: $679,000<K<2,430,000$ and $0.2<r<0.64$.

Nilai $r$ dan $\mathrm{K}$ pada model produksi surplus lebih berasosiasi dengan osilasi perkembangan produksi daripada laju pertumbuhan populasi yang benar. Pertumbuhan organisme adalah hasil proses sangat kompleks yang berkaitan dengan faktor abiotik dan biotik lingkungan, interaksi spesies (pemangsaan dan kompetisi), dan perubahan struktur komunitas (Krebs, 1985). Laju pertumbuhan alami stok tergantung pada besaran stok ikan dan parameter lingkungan. Pada kondisi perairan tanpa dipengaruhi faktor exogeneous dan endogeneous, secara biologi kombinasi $\mathrm{r}$ dan $\mathrm{K}$ dapat menerangkan persaingan ruang dan makanan yang tersedia. Freon (1986) mengatakan bahwa 3 kemungkinan yang dapat mempengaruhi stok, yaitu $r$ tetap dan $\mathrm{K}$ berubah, $\mathrm{r}$ berubah, dan $\mathrm{K}$ tetap atau slope konstan ( $r$ dan $\mathrm{K}$ berubah).

Bagaimana hasil tangkapan mempengaruhi populasi ikan, secara matematik dapat dihitung melalui perubahan biomassa. Dari beberapa parameter produksi surplus dipilih yakni parameter produksi surplus (periode tahun 1988 sampai dengan 2003, tahun 1989 sampai dengan 2003, tahun 1990 sampai dengan 2003, dan tahun 1991 sampai dengan 2003) mewakili parameter yang terkecilterbesar dari fungsi pertumbuhan logistik (Tabel 1) dan fungsi pertumbuhan gompertz (Tabel 2).

Tabel 1.Parameter produksi surplus (model Logistik) berdasarkan pada Gambar 1

Table 1. Parameter of surplus production (Logistic model) based on Figure 1

\begin{tabular}{lccccccc}
\hline Periode/Period & $\begin{array}{c}\mathrm{K} \\
(\mathbf{x} 1.000 \\
\text { ton) }\end{array}$ & $\mathbf{r}$ & $\begin{array}{c}\mathbf{q} \\
(\mathbf{x ~ 1 0} \\
\mathbf{6})\end{array}$ & $\begin{array}{c}\mathbf{C}_{\text {MSY }} \\
(\mathbf{x ~ 1 . 0 0 0} \\
\text { ton) }\end{array}$ & $\begin{array}{c}\mathbf{B}_{\text {MSY }} \\
(\mathbf{x ~ 1 . 0 0 0} \\
\text { ton })\end{array}$ & $\begin{array}{c}\mathbf{E}_{\text {MSY }} \\
(\mathbf{x ~ 1 . 0 0 0} \\
\text { hari) }\end{array}$ & $\begin{array}{c}\text { Keterangan/ } \\
\text { Remarks }\end{array}$ \\
\hline & 508 & 1,05 & 8,3 & 133 & 254 & 63 & WHrata-rata \\
$1988-2003$ & 707 & 0,74 & 6,6 & 131 & 353 & 56 & WH1 \\
$1989-2003$ & 491 & 1,07 & 8,9 & 130 & 245 & 60 & WH2 \\
$1990-2003$ & 470 & 1,11 & 9,12 & 130 & 235 & 61 & WH3 \\
$1991-2003$ & 373 & 1,42 & 1,14 & 132 & 186 & 62 & WH4 \\
\hline
\end{tabular}

Keterangan $/$ Remarks: $\mathrm{C}_{\mathrm{MSY}}=\mathrm{r}^{*} \mathrm{~K} / 4, \mathrm{E}_{\mathrm{MSY}}=\mathrm{r} / 2^{*} \mathrm{q}, \mathrm{B}_{\mathrm{MSY}}=\mathrm{K} / 2$

Tabel 2. Parameter produksi surplus (model Gompertz) berdasarkan pada Gambar 1 Table 2. Parameter of surplus production (Gompertz model) based on Figure 1

\begin{tabular}{rccccccc}
\hline $\begin{array}{r}\text { Periode/ } \\
\text { Period }\end{array}$ & $\begin{array}{c}\mathbf{K} \\
(\mathbf{x ~ 1 . 0 0 0} \\
\text { ton) }\end{array}$ & $\mathbf{r}$ & $\begin{array}{c}\mathbf{q} \\
\left(\mathbf{x ~ 1 0 ^ { - 6 }}\right)\end{array}$ & $\begin{array}{c}\mathbf{C}_{\text {MSY }} \\
(\mathbf{x ~ 1 . 0 0 0} \\
\text { ton })\end{array}$ & $\begin{array}{c}\mathbf{B}_{\text {MSY }} \\
(\mathbf{x ~ 1 . 0 0 0} \\
\text { ton })\end{array}$ & $\begin{array}{c}\mathbf{E}_{\text {MSY }} \\
(\mathbf{x ~ 1 . 0 0 0} \\
\text { hari) }\end{array}$ & $\begin{array}{c}\text { Keterangan/ } \\
\text { Remarks }\end{array}$ \\
\hline & 1.195 & 0,414 & 9,94 & 182 & 440 & 42 & CYPrata-rata \\
$1988-2003$ & 2.427 & 0,206 & 6,57 & 184 & 893 & 31 & CYP1 \\
$1989-2003$ & 1.486 & 0,334 & 9,67 & 182 & 547 & 35 & CYP2 \\
$1990-2003$ & 1.028 & 0,433 & 1,13 & 164 & 378 & 38 & CYP3 \\
$1991-2003$ & 736 & 0,637 & 1,64 & 172 & 270 & 38 & CYP4 \\
\hline
\end{tabular}

Keterangan/Remarks: $\mathrm{C}_{\mathrm{MSY}}=\mathrm{r}^{\star} \mathrm{K}^{\star} \operatorname{Exp}(-1), \mathrm{E}_{\mathrm{MSY}}=\mathrm{r} / \mathrm{q}, \mathrm{B}_{\mathrm{MSY}}=\mathrm{K}^{\star} \operatorname{Exp}(-1)$ 
Pada Gambar 2 memperlihatkan trend biomassa dari fungsi pertumbuhan logistik, di mana besaran biomassa yang belawanan pada tahun 2003, pada nilai laju pertumbuhan $(r)$ rendah (WH1 dan $\mathrm{WH} 2$ ) menunjukkan biomassa cenderung koleps, sebaliknya nilai $r$ yang tinggi (WH3 dan WH4) menunjukkan biomassa cenderung pulih sementara dan biomassa tersisa 7 sampai dengan 30\% (Gambar 3). Sedangkan Gambar 4 memperlihatkan trend biomassa dari fungsi pertumbuhan gompertz cenderung menurun terus dan hanya tersisa sekitar 3,5 sampai dengan $8 \%$.

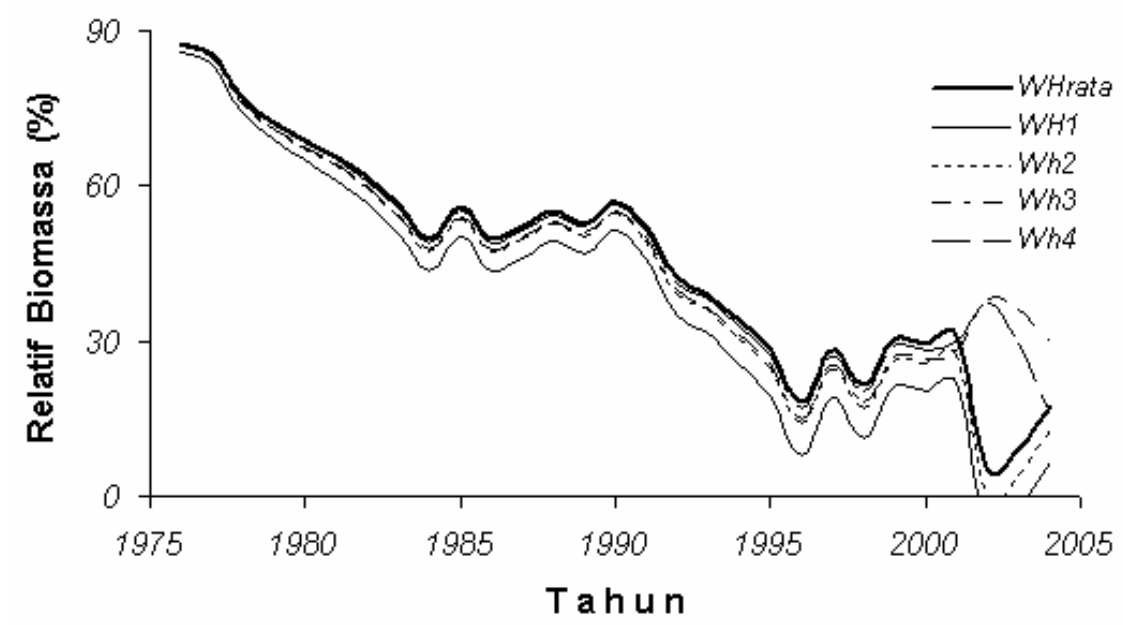

Gambar 3. Dinamika biomassa berdasarkan pada Tabel 1 (logistik). Figure 3. Biomass dynamics based on Table 1 (logistic).

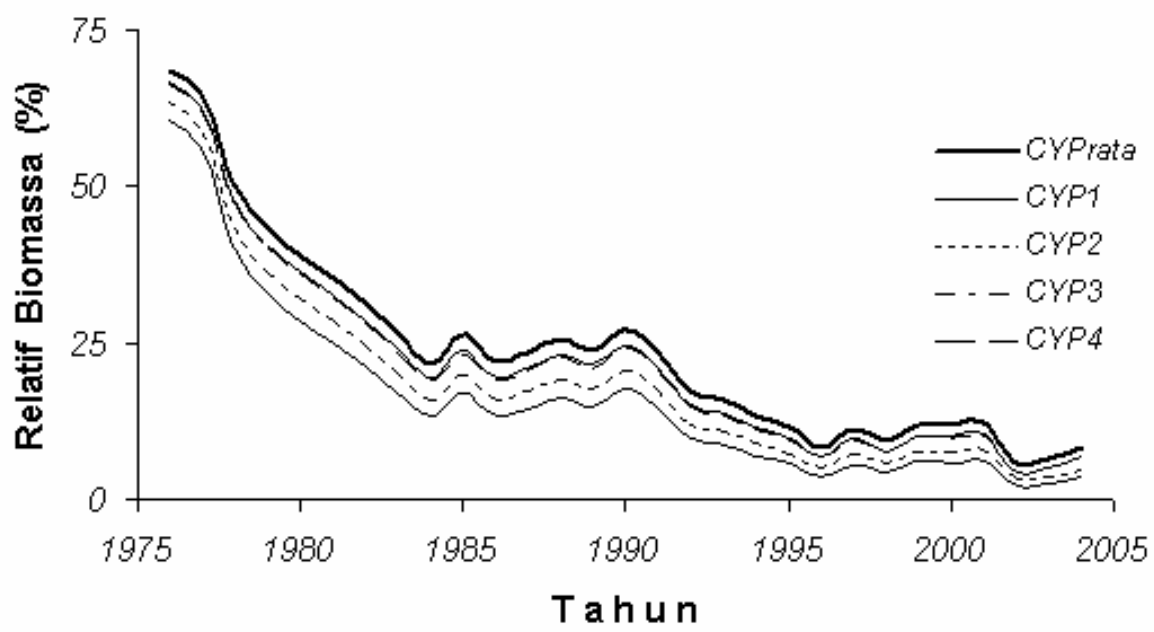

Gambar 4. Dinamika biomassa berdasarkan pada Tabel 2 (Gompertz). Figure 4. Biomass dynamics based on Table 2 (Gompertz).

Tingkat $\mathrm{B}_{\text {MSY }}$ untuk metode Gompertz (37\% dari biomassa awal) telah tercapai pada kurun waktu tahun 1978 sampai dengan 1981 dan untuk metode logistik (50\% dari biomassa) tercapai pada kurun waktu tahun 1990 sampai dengan 1992. Dari kejadian $\mathrm{B}_{\mathrm{MSY}}$ dan $\mathrm{E}_{\mathrm{MSY}}$ menunjukkan perkembangan catch effort perikanan pukat cincin lebih cenderung mengikuti fungsi pertumbuhan logistik daripada fungsi pertumbuhan gompertz (lihat Gambar 1).
Penurunan biomassa tersebut didukung juga oleh peningkatan rata-rata hari beroperasi dan nelayan merasakan semakin sulit menemukan gerombolan ikan. Gerombolan ikan berada di suatu daerah penangkapan hanya dalam waktu singkat, sehingga nelayan sering berpindah-pindah daerah penangkapan untuk memperoleh hasil tangkapan yang memadai. Sinyal lain penurunan stok ikan pelagis kecil juga ditunjukkan oleh rendah produktivitas kapal pukat cincin yakni hasil 
tangkapan hanya separuh kapasitas volume palka (Atmaja, 2002), peningkatan hasil tangkapan ikan ayamayaman (leather jacket, Aluterus monoceros) yang didaratkan di tempat pendaratan ikan Pekalongan dari 4.576 ton (tahun 2002) menjadi 7.344 ton (tahun 2004). Dua tahun terakhir, substitusi alat tangkap (kapal pukat cincin mengganti alat tangkap dengan cantrang) menunjukkan laju eksploitasi sumber daya ikan pelagis kecil lebih besar dibandingkan dengan laju eksploitasi ikan demersal. Indikator lain, setelah ekspansi daerah penangkapan pukat cincin semi industri berlangsung lebih dari 20 tahun, nelayan tradisional di Kalimatan Selatan dan Kalimatan Timur merasakan bahwa banyak kapal pendatang beroperasi menyebabkan hasil tangkapan menurun drastis. Pada akhir tahun 2004, relokasi usaha perikanan mandiri, 8 kapal pukat cincin yang berasal dari Pontianak dan Pekalongan berpindah fishing base ke Bitung (Sulawesi Utara), kemudian diikuti oleh beberapa kapal pukat cincin lain. Beroperasi di perairan Laut Maluku dan Laut Sulawesi.

\section{Implikasi Pengelolaan}

Sejauh ini, evaluasi eksploitasi sumber daya ikan lebih difokuskan terhadap status stok dan kerangka pengelolaan hanya mengacu pada kriteria angka potensi (cenderung tidak berubah) dan maximum sustainable yield, tanpa memperhatikan variabilitas lingkungan global terhadap sumber daya perikanan serta dinamika perikanan yang terjadi. Instrumen pengelolaan melalui konvensional input control upaya penangkapan dan ukuran mata jaring (mechanical selection), tidak termasuk pembatasan berusaha (limited entry), yaitu membatasi jumlah modal, tenaga kerja, dan taktik penangkapan, maka wajar terjadi miss management. Selain itu, perikanan pukat cincin telah mencapai titik jenuh lebih 10 tahun yang lalu. Durand \& Widodo (1997) menyimpulkan tingkat eksploitasi perikanan pukat cincin telah mencapai ambang krisis, yang lebih bersifat sosial ekonomi dari pada bersifat biofisik akibat eksploitasi, yaitu perluasan daerah penangkapan telah mencapai maksimum (hampir seluruh daerah penangkapan di Laut Jawa dan Laut Cina Selatan telah dieksploitasi), pendapatan per kapal menurun (tidak seimbang kenaikan biaya pembekalan dengan nilai jual ikan yang tidak berubah banyak), stagnasi hasil tangkapan pada periode tahun 1992 sampai dengan 1995 menunjukkan bahwa seluruh daerah penangkapan telah dieksploitasi dan hasil tangkapan telah mencapai keseimbangan maximum sustainable yield. Sementara itu, secara alamiah nelayan merespon penyusutan stok ikan dengan merekayasa perlengkapan alat bantu penangkapan dengan teknologi yang lebih maju, sedangkan sikap para perencanaan perikanan, pengembangan usaha perikanan dilakukan melalui peningkatan kemampuan kapal dan perbaikan teknologi alat penangkapan ikan daripada pengelolaan atau pengendalian pemanfaatan. Peningkatan upaya penangkapan (baik jumlah kapal maupun teknologi penangkapan) yang tidak terkendali tersebut, tidak hanya sumber daya ikan yang terkuras, tetapi juga eksploitasi perikanan menjadi tidak efisien secara ekonomi dalam penggunaan tenaga kerja dan modal.

Pendekatan maximum sustainable yield bagi pengelolaan perikanan telah mengalami banyak kritik tajam, sebab selain ketidakstabilan maximum sustainable yield itu sendiri, maximum sustainable yield juga tidak memiliki basis logis pada saat terjadi interaksi antarspesies (Fauzi \& Anna, 2005). Dari hasil penelitian ini membuktikan sumber daya perikanan adalah sumber daya bersifat dinamis. Besaran biomassa dan tingkat $\mathrm{C}_{\mathrm{MSY}}$ dari metode Gompertz lebih tinggi dibandingkan dengan metode logistik, sebaliknya tingkat $\mathrm{E}_{\mathrm{MSY}}$ memperlihatkan bahwa lebih rendah dari metode Gompertz dibandingkan dengan metode logistik.

Di bawah open access motivasi perusahan atau nelayan keuntungan yang sebesar-besarnya yang menjadi faktor dalam menentukan tanggapan terhadap peraturan. Selama ini, kontrol input effort pada perikanan pukat cincin dilakukan langsung oleh nelayan dan individu pemilik kapal. Secara alamiah, nelayan akan merespon penurunan stok ikan dengan merekayasa peningkatan kemampuan tangkap kapal, ukuran kapasitas kapal, jaring dan taktik penangkapan (peningkatkan kemampuan tangkap dengan perlengkapan teknologi yang lebih maju). Dengan demikian, masuk keluar kapal (upaya penangkapan) pada usaha perikanan tidak bersifat statis, upaya penangkapan bergerak mengikuti perubahanperubahan yang terjadi pada sumber daya dan faktor eksternal lain. Pada tingkat biomassa tidak dapat mendukung pada tingkat upaya penangkapan yang sedang berjalan, maka upaya penangkapan akan berkurang secara alami. Martosubroto (2005) mengusulkan perubahan paradigma open access ke limited access, khusus bagi pengelolaan perikanan untuk kapal di bawah 30 GT karena izin penangkapan yang diberikan tidak ada terbatas. Namun demikian, pada kondisi stok ikan pelagis saat ini, pengendalian upaya penangkapan dan hasil tangkapan tidak mungkin dilakukan dengan suatu solusi yang sederhana. Pembatasan jumlah kapal jelas tidak akan efektif sebagai metode kontrol upaya penangkapan tanpa ada kontrol tambahan terhadap kapasitas penangkapan individu dan tak tik penangkapan.

Perikanan pelagis kecil di Laut Jawa telah dihadapkan pada masalah kelebihan kapasitas penangkapan dan 
dinamika alokasi upaya penangkapan. Penerapan pengelolaan perikanan (fisheries management) melalui pengendalian kegiatan penangkapan pada daerah padat tangkap, pemulihan produktivitas sumber daya ikan dan pengendalian pemanfaatan lingkungan sumber daya ikan. Kuota hasil tangkapan dan pembatasan upaya penangkapan dapat mengurangi over exploitation, tetapi regulasi pada perikanan pukat cincin juga harus memperhitungan kenyataan perikanan saat ini seperti a) rata-rata hasil tangkapan jauh lebih rendah dari kapasitas kapal; b) pengurangan subsidi bahan bakar minyak berpengaruh langsung terhadap aktivitas perikanan; dan c) ketidakberdayaan nelayan keluar dari usaha perikanan akibat kesulitan alternatif perkerjaan lain. Rasionalisasi upaya penangkapan akibat semakin terbatas stok ikan pelagis kecil dan kenaikan biaya operasional menimbulkan konsekuensi sosial ekonomi, bagaimana memindahkan sejumlah besar anak buah kapal.

Negara berkewajiban mencegah terjadi overfishing dan kapasitas penangkapan yang berlebihan, serta mengimplementasikan peraturan sehingga tingkat upaya penangkapan seimbang dengan kapasitas produksi dari sumber daya dalam rangka pemanfaatan secara berkelanjutan (code of conduct for responsible fisheries, pasal 6, ayat 3). Dalam rangka implementasi UU 31/2004 tentang perikanan telah melahirkan rencana pengelolaan perikanan Laut Jawa. Upaya pemerintah penerapan rencana pengelolaan perikanan gencar membentuk iklim berusaha perikanan tangkap dengan penataan perizinan yang semakin ketat, serta pembatasan daerah penangkapan. Sebagaimana tertuang dalam rumusan workshop rencana pengelolaan perikanan Laut Jawa yakni menutup secara bertahap penambahan kapal penangkapan baru khusus untuk kapal-kapal >30 GT dan pengalihan kapal penangkapan ke arah kawasan perairan timur Indonesia atau mendorong pengalihan daerah penangkapan ke wilayah pengelolaan perikanan yang dalam kondisi under exploited.

Relokasi usaha perikanan mandiri kapal pukat cincin ke fishing base Bitung dan Bengkulu harus memperhitungkan kecemburuan sosial yang akan timbul dari nelayan lokal, karena penyebab eksternal dari penurunan hasil tangkapan akan dialamatkan kepada nelayan pendatang. Oleh karena itu, daerah penangkapan pada umumnya berasosiasi di sekitar pulau-pulau, maka perizinan penangkapan ikan secara jelas dan tegas melarang kapal pendatang beroperasi di Teluk Tomini, selanjutnya bukti-bukti aktivitas penangkapan didokumenkan dengan baik dan dapat diperlihatkan bahwa tidak beroperasi di daerah penangkapan yang sama dengan nelayan lokal.

\section{KESIMPULAN}

Dari hasil penelitian ini dapat ditarik beberapa kesimpulan, sebagai berikut:

1. Besaran stok ikan bersifat dinamis dan ketidakstabilan tingkat maximum sustainable yield. Dari tingkat biomassa $50 \%\left(\mathrm{~B}_{\mathrm{MSY}}\right)$ dan upaya penangkapan $\left(\mathrm{E}_{\mathrm{MSY}}\right)$ menunjukkan penyebaran data perkembangan perikanan pukat cincin lebih cenderung mengikuti pertumbuhan logistik dari pada pertumbuhan Gompertz.

2. Situasi perikanan pukat cincin di Laut Jawa telah mengalami titik jenuh di mana hasil tangkapan turun drastis. Rekayasa peningkatan alat bantu penangkapan dengan teknologi yang lebih maju sebagai indikator respon terhadap penyusutan stok ikan.

3. Kebijakan berdasarkan pada titik acuan kriteria angka potensi dan maximum sustainable yield tanpa mengetahui laju pertumbuhan stok ikan dan dinamika perikanan akan terjadi mismanagement baik bagi keberlajutan stok ikan maupun bagi keberlangsungan usaha perikanan itu sendiri, karena tingkat maximum sustainable yield telah tercapai pada kurun waktu tahun 1992 sampai dengan 1995. Pengelolaan perikanan baik berdasarkan pada indikator kondisi trend biomassa, perubahan teknologi penangkapan dan kapasitas penangkapan.

4. Penurunan aktivitas penangkapan dan substitusi alat tangkap (kapal pukat cincin mengganti alat tangkap dengan cantrang) menunjukkan masuk keluar kapal (upaya penangkapan) pada usaha perikanan tidak bersifat statis, upaya penangkapan bergerak mengikuti perubahan-perubahan yang terjadi pada sumber daya ikan dan faktor eksternal lain.

\section{Persantunan: \\ Hasil dari kegiatan riset: Perubahan Upaya, Hasil Tangkapan, dan Biologi Populasi Ikan Pelagis Kecil di Laut Cina Selatan, Laut Jawa, dan Selat Makassar T.A. 2005 di Balai Riset Perikanan Laut}

\section{DAFTAR PUSTAKA}

Atmaja, S. B. 2002. Dinamika perikanan purse seine di Laut Jawa dan sekitar. Tesis Program Pascasarjana Institut Pertanian Bogor. 62 hal (tidak dipublikasikan). 
Atmaja S. B. \& B. Sadhotomo. 2000. Variasi geografis hasil tangkapan pukat cincin di bagian selatan Paparan Sunda. Prosiding Seminar Keanekaragaman Hayati Ikan. Pusat Studi Ilmu Hayati Institut Pertanian Bogor. Pusat Penelitian dan Pengembangan Biologi. Lembaga Ilmu Pengetahuan Indonesia. 221-218.

Badrudin \& S. Blaber. 2003. Pengkajian stok sumber daya ikan kakap merah di perairan Laut Arafuru dan Laut Timor. Prosiding Forum Pengkajian Stok Ikan Laut 2003. Pusat Riset Perikanan Tangkap. Badan Riset Kelautan dan Perikanan. Departemen Kelautan dan Perikanan. 47-56.

Bailey, C. A. Dwiponggo, \& F. Marahuddin. 1987. Indonesian marine capture fisheries. ICLARM Studies and reviews. 10. $196 \mathrm{p}$.

Caddy, J. F. \& R. Mcgarney. 1996. Targets or limits for management of fisheries. North American Journal Fisheries Management. American Fisheries Society. Vol.16 (3): 479-487.

Charles, T. A. 2001. Sustainable fishery systems. Blackwell Science Ltd. London. $370 \mathrm{p}$.

Clarke, R. P., S. S. Yoshimoto, \& S. G. Pooley. 1992. A bioeconomic analysis of the North-Western Hawaiian Islands. Lobster Fishery. Marine Resources Economics. 7 (2): 115-140.

Direktorat Jenderal Perikanan Tangkap. 2004. Pencapaian pembangunan perikanan tangkap tahun 2001 sampai dengan 2003. Departemen Kelautan dan Perikanan. Direktorat Jenderal Perikanan Tangkap. $57 \mathrm{p}$.

Doll, J. 1988. Tradisional economic models of fishing vessels: A review with discussion. Marine Resource Economics. Vol (5): 99-123.

Durand, J. R. \& J. Widodo. 1997. Final report Java Sea pelagic fishery assessment project (ALA/INS/87/17). AARD-ORSTOM/EEC. Sci. and Tech. Doc. No.26. $76 \mathrm{p}$.
Dwiponggo, A. 1983. Pengkajian sumber daya perikanan laut di Laut Jawa. Laporan Penelitian Perikanan Laut. No.28: 13-33.

Fauzi, A. 1999. An econometric analysis for the surphus production model and its application for tropical fisheries. Working paper Institute of Fisheries Analysis. Simon Fraser University. British Columbia. Canada. $18 \mathrm{p}$.

Fauzi, A. \& Anna, S. 2005. Pemodelan sumber daya perikanan dan kelautan untuk analisis kebijakan. Gramedia. Jakarta. 335 p.

Freon, P. 1986. Introduction of environmental variables into global production models. Inst. Symp. Long Term Changes Marine Fisheries Pop. Vigo. 481-528.

Hilborn, R. \& C. J. Walters. 1992. Quantitative fisheries stock assessment: Choice, dynamics, and uncertainty. Chapman and Hall. New York. London. $570 \mathrm{p}$.

Krebs, C. J. 1985. Ecology, the experimental analysis of distribution and abundance. Harper \& Row. Publishers. New York. 800 p.

Marr, J. C. 1981. Southeast Asian marine fishery resources and fisheries. In C. Mac Andrews and L. S. Chia (Eds.) Southeast Asian Seas. McGraw-Hill International Book Company. Singapore. 75-109.

Martosubroto, P. 2005. Menuju pengelolaan perikanan yang bertanggungjawab. Makalah disampaikan pada Forum Pengkajian Stok Ikan Laut 2005. Hotel Bintang. 27-28 Desember 2005.

Seijo J. C., O. Defeo, \& S. Salas. 1998. Fisheries bioeconomics: Theory, modeling, and management. FAO Fish. Tech. Paper 368. FAO-UN. 108 p.

Sumadiharga, O. K. 2000. Potensi sumber daya perikanan Laut Indonesia. Prosiding Seminar Kelautan. 142-157.

Diterima tanggal: 3 Agustus 2005

Diterima setelah perbaikan tanggal: 29 Juni 2006

Disetujui terbit tanggal: 8 September 2006 
Lampiran 1. Perkembangan produksi ikan dan upaya penangkapan pukat cincin di tempat pendaratan ikan Pekalongan dan Juwana, selama tahun 1976 sampai dengan 2004

Appendix 1. The development of total production of fish and effort of purse seine in Pekalongan and Juwana landing place, during the periods 1976 to 2004

\begin{tabular}{|c|c|c|c|c|c|}
\hline Tahun/Year & $\begin{array}{c}\text { Upaya } \\
\text { penangkapan/ } \\
\text { Fishing effort } \\
\text { (Trip) }\end{array}$ & $\begin{array}{c}\text { Upaya } \\
\text { penangkapan/ } \\
\text { Fishing effort } \\
\text { (Hari) }\end{array}$ & $\begin{array}{l}\text { Produksi// } \\
\text { Production* } \\
\text { (ton) }\end{array}$ & $\begin{array}{c}\text { Pukat } \\
\text { cincin/Purs } \\
\text { e seine } \\
\text { DGF }^{\star *} \text { (ton) }\end{array}$ & $\begin{array}{c}5 \text { kategori } \\
\text { komersial/Five } \\
\text { commercial } \\
\text { category } \\
\text { DGF }^{\star \star \star} \text { (ton) }\end{array}$ \\
\hline 1976 & 3.930 & 15.720 & 10.899 & 35.839 & 116.968 \\
\hline 1977 & 4.625 & 18.500 & 12.740 & 49.633 & 134.863 \\
\hline 1978 & 5.760 & 28.800 & 17.236 & 56.122 & 140.784 \\
\hline 1979 & 5.950 & 35.059 & 21.231 & 71.892 & 161.789 \\
\hline 1980 & 5.918 & 39.236 & 24.303 & 84.474 & 162.812 \\
\hline 1981 & 5.389 & 43.542 & 21.720 & 77.940 & 170.780 \\
\hline 1982 & 5.935 & 48.492 & 28.273 & 91.277 & 178.739 \\
\hline 1983 & 5.896 & 55.327 & 45.807 & 116.914 & 190.585 \\
\hline 1984 & 5.709 & 63.511 & 56.264 & 134.357 & 213.011 \\
\hline 1985 & 5.132 & 55.931 & 82.824 & 161.611 & 242.635 \\
\hline 1986 & 4.702 & 63.484 & 83.003 & 152.673 & 233.574 \\
\hline 1987 & 3.948 & 60.465 & 59.503 & 125.708 & 206.027 \\
\hline 1988 & 3.709 & 56.865 & 47.884 & 124.141 & 223.548 \\
\hline 1989 & 4.173 & 59.636 & 65.660 & 165.453 & 265.613 \\
\hline 1990 & 3.914 & 54.532 & 71.903 & 185.191 & 280.872 \\
\hline 1991 & 4.098 & 60.569 & 102.780 & 207.909 & 321.505 \\
\hline 1992 & 4.537 & 73.221 & 129.719 & 252.609 & 326.115 \\
\hline 1993 & 4.230 & 76.929 & 115.217 & 221.804 & 303.856 \\
\hline 1994 & 4.476 & 83.525 & 144.200 & 278.010 & 362.270 \\
\hline 1995 & 4.231 & 90.267 & 123.386 & 266.320 & 363.297 \\
\hline 1996 & 4.538 & 103.283 & 110.278 & 256.909 & 345.205 \\
\hline 1997 & 3.890 & 90.760 & 115.405 & 284.294 & 367.401 \\
\hline 1998 & 4.331 & 99.370 & 118.077 & 275.423 & 371.343 \\
\hline 1999 & 3.610 & 88.457 & 85.914 & 240.381 & 318.641 \\
\hline 2000 & 3.304 & 89.244 & 82.952 & 217.531 & 311.871 \\
\hline 2001 & 3.075 & 87.240 & 93.622 & 246.168 & 347.980 \\
\hline 2002 & 4.134 & 120.296 & 85.337 & 237.740 & 384.977 \\
\hline 2003 & 3.900 & 114.937 & 83.936 & 219.384 & 329.153 \\
\hline 2004 & 3.547 & 104.559 & 79.029 & & \\
\hline
\end{tabular}

Keterangan/Remarks: * Produksi perikanan pukat cincin Pekalongan dan Juwana; ** Produksi perikanan pukat cincin; ${ }^{* * *}$ layang, kembung, lemuru, selar, dan tembang 
Lampiran 2a. Parameter produksi surplus (model pertumbuhan logistik)

Appendix 2a. Parameters of surplus production (logistic growth model)

\begin{tabular}{ccccc}
\hline Periode/Period & $\mathbf{r}$ & $\begin{array}{c}\mathbf{q} \\
\mathbf{( x ~ 1 0 - 6})\end{array}$ & $\begin{array}{c}\mathbf{K} \\
(\mathbf{x} \mathbf{1 . 0 0 0} \text { ton })\end{array}$ & $\begin{array}{c}\text { Koefisien } \\
\text { determinasi/Determinati } \\
\text { coefisient } \mathbf{R}^{\mathbf{2}}\end{array}$ \\
\hline $1988-2001$ & 0,648 & 5,56 & 766 & 0,34 \\
$1988-2002$ & 0,672 & 5,09 & 684 & 0,34 \\
$1988-2003$ & 0,741 & 6,61 & 707 & 0,44 \\
$1988-2004$ & 0,746 & 5,87 & 618 & 0,33 \\
$1989-2001$ & 0,989 & 8,08 & 520 & 0,65 \\
$1989-2002$ & 1,013 & 7,82 & 489 & 0,64 \\
$1989-2003$ & 1,068 & 8,90 & 491 & 0,71 \\
$1989-2004$ & 1,074 & 8,17 & 451 & 0,63 \\
$1990-2001$ & 0,992 & 8,10 & 518 & 0,56 \\
$1990-2002$ & 1,04 & 8,00 & 480 & 0,56 \\
$1990-2003$ & 1,107 & 9,12 & 470 & 0,65 \\
$1990-2004$ & 1,128 & 8,50 & 429 & 0,62 \\
$1991-2001$ & 1,316 & 10,6 & 402 & 0,56 \\
$1991-2002$ & 1,365 & 10,73 & 381 & 0,59 \\
$1991-2003$ & 1,42 & 11,40 & 373 & 0,58 \\
$1991-2004$ & 1,438 & 10,75 & 348 & 0,58 \\
\hline Rata-rata & $\mathbf{1 , 0 5}$ & $\mathbf{8 , 3 3}$ & $\mathbf{5 0 8}$ & \\
\hline
\end{tabular}

Lampiran 2b. Parameter produksi surplus (model pertumbuhan gompertz)

Appendix $2 b$. Parameters of surplus production (gompertz growth model)

\begin{tabular}{ccccc}
\hline Periode/Period & $\mathbf{r}$ & $\begin{array}{c}\mathbf{q} \\
\left.\mathbf{( x ~ 1 0 ^ { - 6 }}\right)\end{array}$ & $\begin{array}{c}\mathbf{K} \\
(\mathbf{x ~ 1 . 0 0 0 ~ t o n )}\end{array}$ & $\begin{array}{c}\text { Koefisien determinasi/ } \\
\text { Determinati coefisient } \\
\mathbf{R}^{\mathbf{2}}\end{array}$ \\
\hline $1988-2001$ & 0,418 & 7,20 & 777 & 0,55 \\
$1988-2002$ & 0,306 & 3,92 & 919 & 0,53 \\
$1988-2003$ & 0,206 & 6,57 & 2.427 & 0,6 \\
$1988-2004$ & 0,264 & 6,27 & 1.336 & 0,61 \\
$1989-2001$ & 0,263 & 8,90 & 2.409 & 0,66 \\
$1989-2002$ & 0,418 & 7,20 & 777 & 0,62 \\
$1989-2003$ & 0,334 & 9,67 & 1.486 & 0,7 \\
$1989-2004$ & 0,384 & 9,53 & 1.069 & 0,72 \\
$1990-2001$ & 0,31 & 9,69 & 1.820 & 0,64 \\
$1990-2002$ & 0,485 & 8,36 & 678 & 0,61 \\
$1990-2003$ & 0,433 & 11,30 & 1.028 & 0,71 \\
$1990-2004$ & 0,477 & 11,40 & 848 & 0,73 \\
$1991-2001$ & 0,422 & 13,79 & 1.531 & 0,67 \\
$1991-2002$ & 0,61 & 12,16 & 606 & 0,63 \\
$1991-2003$ & 0,637 & 16,42 & 735 & 0,74 \\
$1991-2004$ & 0,665 & 16,60 & 679 & 0,76 \\
\hline Rata-rata & $\mathbf{0 , 4 1 5}$ & $\mathbf{9 , 9 4}$ & $\mathbf{1 . 1 9 5}$ & \\
\hline
\end{tabular}

